\title{
Correlation and Path Coefficient Analysis Studies in Pumpkin (Cucurbita moschata Duch. Ex poir) for Yield and Quality Traits
}

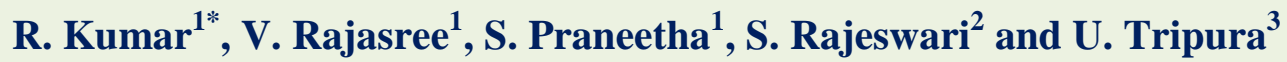 \\ ${ }^{1}$ Department of Vegetable Crops, ${ }^{3}$ Department of Spice and Plantation Crops, \\ Horticulture College and Research Institute, TNAU, Coimbatore-641003, India \\ ${ }^{2}$ Centre for Plant Breeding and Genetics, Agriculture College and Research Institute, TNAU, \\ Coimbatore-641003, India \\ *Corresponding author
}

A B S T R A C T

\begin{tabular}{|l|}
\hline K e y w o r d s \\
$\begin{array}{l}\text { Correlation, } \text { Cucurbita } \\
\text { moschata, } \text { Path analysis, } \\
\beta \text {-carotene }\end{array}$ \\
\hline Article Info \\
\hline $\begin{array}{l}\text { Accepted: } \\
22 \text { April } 2018 \\
\text { Available Online: } \\
10 \text { May } 2018\end{array}$ \\
\hline
\end{tabular}

\section{Introduction}

Pumpkin (Cucurbita moschata Duch. Ex. Poir) is locally known as "kaddu" in India. It belongs to the family Cucurbitaceae having chromosome number $2 \mathrm{n}=40$. This crop is native of Northern and Southern America. There are 27 species under the genus Cucurbita, five of which are in cultivation. These are $C$. moschata, $C$. maxima, $C$. ficifolia, C. pepo and C. Mixta. Commonly known as pumpkin $C$. moschata is probably the most widely grown species of cucurbita
The present experiment was conducted to study correlation and path analysis for yield and quality traits of 28 genotypes. Significant variations were found among the genotypes for characters studied. The correlation coefficient analysis at genotypic level revealed that fruit yield per vine had positive and significant association with fruit number per vine (0.85), fruit weight (0.613), fruit equatorial diameter (0.53), ascorbic acid content (0.69) and crude fibre content (0.49). Path coefficient analysis at genotypic level revealed that number of fruits per vine exerted the highest positive direct effect (3.64) on total yield per plant followed by sex ratio (2.29), fruit polar diameter (1.83), days to first harvest (1.57) and fruit equatorial diameter (0.92). Besides this negative direct effect on yield per plant was recorded by 100 seed weight $(-2.06)$, ascorbic acid content $(-1.12)$, fruit weight ($1.03), \beta$-carotene $(-0.90)$ and days to first female flower appearance $(-0.39)$.

and it is cross compatible with $C$. maxima, $C$. pepo and C. mixta (Tindall, 1957). Pumpkin is relatively high in energy and carbohydrates and a good source of vitamins, especially high carotenoid pigments and minerals (Bose and Som, 1998). Pumpkin can be used at immature and mature stages. Yellow or orange fleshed pumpkins are rich in carotene. Pumpkin young leaves, tender stems and flowers are also cooked and consumed. It may contribute to improve the nutritional status of the people, particularly the vulnerable groups in respect of vitamin-A requirement. 
Efficient management and utilization of the germplasm requires detailed knowledge of the genetic diversity of economically important traits for proper characterization of populations to facilitate efficient generation of breeding populations that are designed to achieve specific objectives. A crop breeding programme, aimed at increasing plant productivity requires consideration not only of yield but also its components that have direct or indirect bearing on yield. Correlation coefficient empowers a breeder to know the degree of association between the independent and dependent variable fruits. Path coefficient analysis measures direct influence of one variable upon another and permits separation of correlation coefficient in component direct and indirect effect, which can be used for crop improvement through selection of component traits. Therefore, the present study was undertaken to estimate the correlation coefficients and path-coefficient and to screen out the suitable parental groups with better performance for future breeding program in the twenty eight genotypes of pumpkin.

\section{Materials and Methods}

The present investigation was carried out at University orchard, Department of Vegetable Crops, Horticultural College and Research Institute, Tamil Nadu Agricultural University, Coimbatore during the year 2017. The experimental material for the present study consisted of twenty eight genotypes (include parents, hybrids and standard check) of pumpkin. The seeds of twenty eight genotypes of pumpkin were sown in the field during 2017 for comparative evaluation on various quantitative traits. The experiment was laid out in a Randomized Block Design with two replications of each genotype. Two to three seeds of each genotype were sown in the pits at a spacing of $1.5 \times 2 \mathrm{~m}$. The standard cultural practices as mentioned in package of practices for vegetables crops by Thamburaj and Singh
(2004) were followed to raise the healthy crop stand. The fruits were harvested when peduncle dried on maturity.

Days to first mature fruit was calculated from date of planting to first mature fruit harvest. Fruit polar diameter was recovered at mature fruit stage and measured in each fruit from fruit stalk end to stylar end. Equatorial diameter of fruit was recorded at broadcast point in each fruit. Mature fruit weight from each plant in each treatment was recorded and their average weight was calculated number of fruits per vine was calculated by fruits harvested on observational plants and counted at each harvest. Flesh thickness was measured at maximum fruit diameter i.e. at the broadest point with the help of scale. Yield per vine was calculated by total weight of fully matured fruits of all the harvests divided by number of plants. The mean values of data recorded for different traits were subjected to analysis of variance Gomez and Gomez (1984). The genotypic correlations were calculated by using TNAU STAT software.

\section{Results and Discussion}

The analysis of variance indicated significant differences between the genotypes for all the studied traits. Association analysis split the correlation coefficient into direct and indirect effect, to measure the relative importance of each character. The genotypic correlation coefficients between yield per vine and its component traits and inter-correlation among different traits are presented in Table 1.

Fruit yield per vine recorded positive and significant association with fruit number per vine (0.85), fruit weight (0.613), ascorbic acid content (0.692), fruit equatorial diameter (0.528), and crude fiber content (0.496) flesh thickness (0.480), vine length (0.448) and polar diameter (0.413). However, it also recorded negative and significant association 
with sex ratio (-0.822), days to first female flower appearance $(-0.541)$ and days to first harvest $(-0.514)$. The node number for first female flower appearance (0.236), number of seeds per fruit (0.187), seed weight per fruit $(0.162)$ and carotene content $(0.114)$ were observed positive and non-significant association with yield.

\section{Inter-correlation among yield components and quality traits}

Vine length exhibited positive and significant association with fruit number per vine $(0.60)$ and negative and significant association with sex ratio (-0.704). The correlation of days to first female flower appearance $(-0.191)$, days to first harvest (-0.305), 100 seed weight (0.110 ) and carotene content with fruit yield showed negative and non-significant effects. It also showed non-positive and significant association with node number for first female flower appearance (0.029), fruit weight (0.246), fruit equatorial diameter (0.353), fruit polar diameter (0.078), fruit thickness (0.303), number seeds per fruit $(0.261)$, seed weight per fruit (0.155), ascorbic acid content $(0.245)$ and crude fiber content $(0.247)$.

Days to first female flowers appearance recorded positive and significant association with sex ratio (0.490) and days to first harvest (0.592). However, it showed positive and nonsignificant association with node number for first female flower appearance (0.09), 100 seed weight (0.303). It was also noticed that it showed negative and significant relation with number of fruits per vine $(-0.518)$.

It showed negative but non-significant association with fruit weight $(-0.24)$, fruit equatorial diameter $(-0.38)$, fruit polar diameter (-0.10), flesh thickness (-0.18), seed number per fruit $(-0.31)$, seed weight $(-0.26)$, ascorbic acid content (-0.45) crude fibre content $(-0.39)$ and carotene content $(0.10)$.
Node number for first female flower appearance showed positive and significant association with ascorbic acid content (0.46). It showed positive and non-significant association with number of fruits per vine (0.14), fruit weight (0.13), fruit equatorial diameter(0.03), fruit polar diameter (0.11), flesh thickness (0.07), number of seeds per fruit (0.28), seed weight per fruit (0.27), crude fiber content (0.22) and carotene content (0.008). It was also noticed that it showed negative and non-significant relation with sex ratio $(-0.17)$, days to first harvest $(-0.30)$ and 100 seed weight $(-0.12)$. Sex ratio registered negative and significant correlation with number of fruits per vine (-0.92), fruit weight $(-0.48)$, fruit equatorial diameter $(-0.56)$, flesh thickness (-0.50), ascorbic acid (-0.56) and crude fiber (-0.46). It showed negative and non-significant correlation with fruit polar diameter $(-0.20)$, number of seeds per fruit $(0.27)$, seed weight per fruit $(-0.25)$ and carotene (-0.13). However positive and nonsignificant correlation of sex ratio was observed with days to first harvest (0.35) and 100 seed weight (0.07). Days to first harvest registered positive and non-significant correlation with 100 seed weight $(0.56)$. It shows negative and non-significant correction with number of fruits per vine (-0.42), fruit weight (-0.21), fruit equatorial diameter (0.31 , fruit polar diameter (-0.27), flesh thickness (-0.19), seed weight per fruit (-0.02), crude fiber (-0.44) and carotene content (0.08 ). It showed negative and significant correlation with number of seeds per fruit ($0.47)$ and ascorbic acid content (-0.65). Number of fruits per vine had positive and non-significant association with fruit weight (0.32), fruit equatorial diameter (0.36), fruit polar diameter (0.25), flesh thickness (0.42), number of seeds per fruit (0.06), seed weight per fruit (0.02) and carotene content (0.36). It showed positive and significant association with ascorbic acid (0.62) and crude fiber content (0.49) were. It showed negative and 
non-significant correlation with 100 seed weight (-0.10). Fruit weight had positive and significant correlation with fruit equatorial diameter (0.72), fruit polar diameter (0.51) and flesh thickness (0.63), ascorbic acid content (0.54).

Number of seeds per fruit (0.34), seed weight per fruit (0.23) and crude fibre content (0.29) were positive but non-significantly correlated with fruit weight. However, 100 seed weight (-0.06) and carotene content (-0.21) showed negative and non-significant association. Fruit equatorial diameter had positive and nonsignificant correlation with fruit polar diameter (0.25), seed number per fruit $(0.30)$, seed weight per fruit (0.28), ascorbic acid (0.39) and crude fiber (0.20). Flesh thickness (0.48) was positive but significant association with fruit equatorial diameter. It also showed negative and non-significant correlation with 100 seed weight $(-0.07)$ and carotene content (-0.13). Fruit polar diameter showed positive and significant association with ascorbic acid (0.50). Flesh thickness (0.27), seed weight per fruit (0.26), 100 seed weight $(0.41)$, crude fibre content (0.27) and carotene content (0.22) showed positive and non- significant relation. It showed negative and nonsignificant correlation with number of seeds per fruit (-0.21). Flesh thickness had positive and significant association with ascorbic acid (0.54) and crude fiber (0.61).

It showed positive and non-significant association correlation with number of seeds per fruit (0.31), seed weight per fruit (0.14) and carotene content (0.16). It showed negative and non-significant association with 100 seed weight (-0.13). Number of seeds per fruit had registered positive and nonsignificant correlation with seed weight per fruit (0.38), ascorbic acid content (0.29) and crude fiber (0.13). It showed negative and non-significant relation with carotene content $(-0.37)$. Seed weight per fruit showed positive and significant correlation with100 seed weight (0.45). Ascorbic acid content (0.11) and crude fiber content (0.12) showed positive and non-significant association. It was also observed that carotene content (-0.26) showed negative and non-significant association with seed weight. The 100 seed weight showed positive and non-significant correlation with carotene content (0.07). Ascorbic acid content $(-0.27)$ and crude fiber content $(-0.88)$ were negative and non-significant correlation with 100 seed weight. Ascorbic acid content showed positive and significant correlation with crude fiber content (0.60). It showed positive and non-significant correlation carotene content (0.18). Crude fiber content showed positive and non-significant correlation with carotene content (0.14) however, positive and significant correlation with fruit yield per vine (0.496). The $\beta$ carotene showed positive and non-significant correlation with fruit yield per vine (0.114).

Yield is a complex entity associated with a number of component characters. According to Graffius (1964), all changes in yield must be accomplished by changes in one or more characters. However, all the changes in the components need not be expressed by changes in the yield and might be due to the varying degree of positive and negative correlation between yield and its components and among the components themselves. The study of association of these characters helps in selection of the genotypes and also to suggest the advantage of a scheme of selection for more than one character at a time (Kalloo, 1998). In the present investigation fruit number per vine, fruit weight, fruit equatorial diameter, ascorbic acid and crude fibre content had highly positive significant influence on fruit yield per vine in pumpkin. Pandey et al., (2002) and Hazara et al., (2007) reported similar line of results where the yield was positively and significantly correlated with fruit number per vine. 


\section{Int.J.Curr.Microbiol.App.Sci (2018) 7(5): 3067-3075}

Table.1 Genotypic correlation between yield and different traits in pumpkin

\begin{tabular}{|c|c|c|c|c|c|c|c|c|c|c|c|c|c|c|c|c|c|}
\hline Characters & 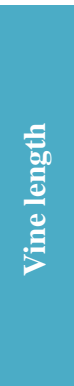 & 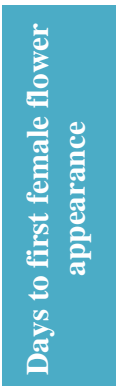 & 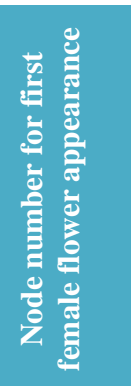 & 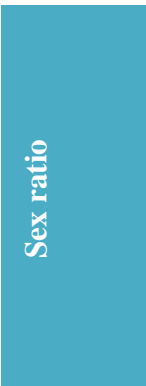 & 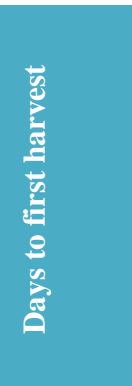 & 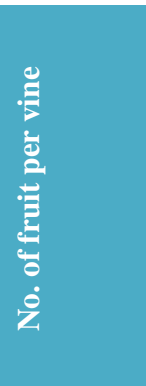 & 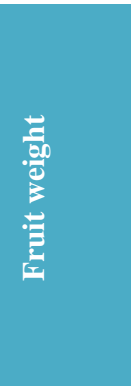 & 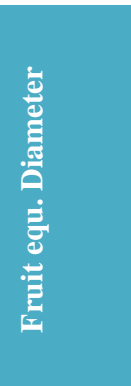 & 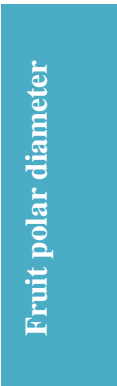 & 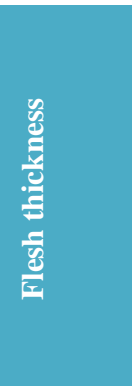 & 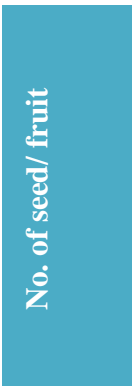 & 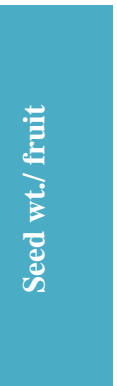 & 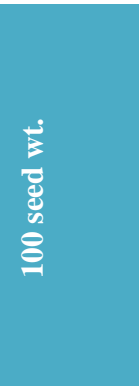 & 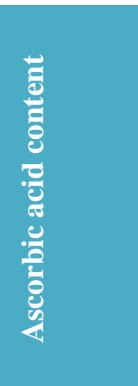 & 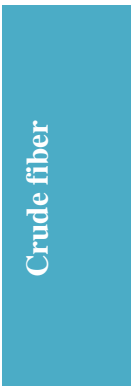 & 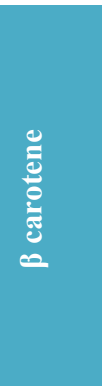 & 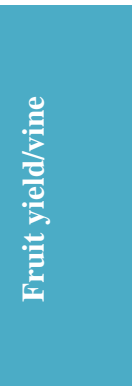 \\
\hline Vine length & 1 & -0.191 & 0.029 & $-0.704 * *$ & -0.305 & $0.601^{*}$ & 0.246 & 0.353 & 0.078 & 0.303 & 0.261 & 0.155 & -0.110 & 0.245 & 0.247 & -0.169 & $0.448^{*}$ \\
\hline $\begin{array}{l}\text { Days to first female } \\
\text { flower appearance } \\
\end{array}$ & & 1 & 0.090 & $0.490^{*}$ & $0.592 * *$ & $-0.518^{*}$ & -0.242 & -0.388 & -0.100 & -0.187 & -0.316 & -0.026 & 0.303 & $-0.454^{*}$ & -0.397 & -0.108 & $-0.541^{*}$ \\
\hline $\begin{array}{l}\text { Node number for } \\
\text { first female flower } \\
\text { appearance }\end{array}$ & & & 1 & -0.177 & -0.309 & 0.142 & 0.137 & 0.032 & 0.116 & 0.077 & 0.287 & 0.277 & -0.120 & $0.468^{*}$ & 0.224 & 0.008 & 0.236 \\
\hline Sex ratio & & & & 1 & 0.356 & $-0.921 * *$ & $-0.482 *$ & $-0.561 * *$ & -0.202 & $-0.506^{*}$ & -0.274 & -0.257 & 0.071 & $-0.569^{* *}$ & $-0.469^{*}$ & -0.136 & $-0.822 * *$ \\
\hline Days to first harvest & & & & & 1 & -0.424 & -0.216 & -0.312 & -0.278 & -0.191 & $-0.479^{*}$ & -0.025 & $0.567 * *$ & $-0.653^{* *}$ & $-0.441^{*}$ & -0.086 & $-0.514^{*}$ \\
\hline No. of fruit per vine & & & & & & 1 & 0.328 & 0.366 & 0.253 & $0.424 *$ & 0.061 & 0.022 & -0.105 & $0.620^{* *}$ & $0.497 *$ & 0.366 & $0.850 * *$ \\
\hline Fruit weight & & & & & & & 1 & $0.721 * *$ & $0.516^{*}$ & $0.639 * *$ & 0.341 & 0.231 & -0.068 & $0.548^{* *}$ & 0.294 & -0.215 & $0.613^{* *}$ \\
\hline Fruit equ. Diameter & & & & & & & & 1 & 0.252 & $0.485^{*}$ & 0.305 & 0.286 & -0.078 & 0.398 & 0.207 & -0.139 & $0.528 *$ \\
\hline Flesh thickness & & & & & & & & & & 1 & 0.314 & 0.147 & -0.131 & $0.547^{* *}$ & $0.612^{* *}$ & 0.164 & $0.480^{*}$ \\
\hline No. of seed / fruit & & & & & & & & & & & 1 & 0.383 & $-0.601 * *$ & 0.294 & 0.130 & -0.372 & 0.187 \\
\hline Seed wt./ fruit & & & & & & & & & & & & 1 & $0.458 *$ & 0.113 & 0.120 & -0.266 & 0.162 \\
\hline 100 seed wt. & & & & & & & & & & & & & 1 & -0.279 & -0.088 & 0.079 & -0.128 \\
\hline $\begin{array}{l}\text { Ascorbic acid } \\
\text { content }\end{array}$ & & & & & & & & & & & & & & 1 & $0.609^{* *}$ & 0.181 & $0.692^{* *}$ \\
\hline Crude fiber & & & & & & & & & & & & & & & 1 & 0.149 & $0.496^{*}$ \\
\hline$\beta$ carotene & & & & & & & & & & & & & & & & 1 & 0.114 \\
\hline Fruit yield/vine & & & & & & & & & & & & & & & & & 1 \\
\hline
\end{tabular}


Table.2 Path analysis for different traits in pumpkin

\begin{tabular}{|c|c|c|c|c|c|c|c|c|c|c|c|c|c|c|c|c|c|c|c|c|c|c|}
\hline & 1 & 2 & 3 & \multicolumn{3}{|c|}{4} & 5 & 6 & & \multicolumn{2}{|c|}{7} & 8 & 9 & 10 & 11 & 12 & 13 & \multicolumn{2}{|c|}{14} & 15 & 16 & 17 \\
\hline 1 & -0.3291 & 0.0784 & 0.0166 & \multicolumn{3}{|c|}{-1.6222} & -0.4867 & 2.19 & & \multicolumn{2}{|c|}{-0.2577} & 0.3293 & 0.1452 & 0.1262 & -0.0298 & 0.1401 & 0.2257 & \multicolumn{2}{|c|}{-0.2754} & 0.0359 & 0.1541 & 0.4497 \\
\hline 2 & 0.0649 & -0.3977 & 0.053 & \multicolumn{3}{|c|}{1.142} & 0.9443 & -1.90 & & \multicolumn{2}{|c|}{0.2535} & -0.3661 & -0.1884 & -0.077 & 0.0364 & -0.0268 & -0.6298 & \multicolumn{2}{|c|}{0.5123} & -0.0579 & 0.098 & -0.546 \\
\hline 3 & -0.0096 & -0.0369 & 0.5714 & \multicolumn{3}{|c|}{-0.4101} & -0.4903 & $0.51 \varepsilon$ & & \multicolumn{2}{|c|}{-0.1431} & 0.0298 & 0.2134 & 0.0317 & -0.0328 & 0.2473 & 0.2465 & \multicolumn{2}{|c|}{-0.5249} & 0.0324 & -0.0072 & 0.2362 \\
\hline 4 & 0.2328 & -0.1981 & -0.1022 & \multicolumn{3}{|c|}{2.2931} & 0.5679 & -3.36 & & \multicolumn{2}{|c|}{0.5008} & -0.522 & -0.3705 & -0.209 & 0.0314 & -0.2296 & -0.1481 & \multicolumn{2}{|c|}{0.6381} & -0.0675 & 0.1238 & -0.824 \\
\hline 5 & 0.1015 & -0.238 & -0.1776 & \multicolumn{3}{|c|}{0.8255} & 1.5775 & -1.55 & & \multicolumn{2}{|c|}{0.2268} & -0.2924 & -0.5146 & -0.079 & 0.0552 & -0.0215 & -1.1796 & \multicolumn{2}{|c|}{0.739} & -0.064 & 0.0788 & -0.5188 \\
\hline 6 & -0.1988 & 0.2083 & 0.0814 & \multicolumn{3}{|c|}{-2.1193} & -0.6745 & 3.635 & & \multicolumn{2}{|c|}{-0.3408} & 0.34 & 0.4658 & 0.1751 & -0.0069 & 0.0197 & 0.2175 & \multicolumn{2}{|c|}{-0.696} & 0.0718 & -0.3323 & 0.8508 \\
\hline 7 & -0.0818 & 0.0972 & 0.0789 & \multicolumn{3}{|c|}{-1.1075} & -0.3451 & 1.196 & & \multicolumn{2}{|c|}{-1.0368} & 0.6699 & 0.9494 & 0.2644 & -0.0392 & 0.2059 & 0.1405 & \multicolumn{2}{|c|}{-0.6153} & 0.0423 & 0.1948 & 0.6139 \\
\hline 8 & -0.1172 & 0.1575 & 0.0184 & \multicolumn{3}{|c|}{-1.295} & -0.4991 & 1.33 & & \multicolumn{2}{|c|}{-0.7515} & 0.9242 & 0.4641 & 0.2012 & -0.035 & 0.2549 & 0.1594 & \multicolumn{2}{|c|}{-0.4468} & 0.0298 & 0.1261 & 0.5301 \\
\hline 9 & -0.0261 & 0.0409 & 0.0665 & & -0.4 & & -0.4431 & 0.925 & & -0.5 & 373 & 0.2341 & 1.8323 & 0.1118 & 0.0248 & 0.2318 & -0.8479 & -0.5 & 736 & 0.0401 & -0.2016 & 0.4145 \\
\hline 10 & -0.1006 & 0.0747 & 0.0438 & & -1.16 & 655 & -0.3017 & 1.543 & & -0.6 & & 0.4505 & 0.4961 & 0.4128 & -0.0358 & 0.1303 & 0.2715 & -0.6 & 144 & 0.0881 & -0.1488 & 0.4809 \\
\hline 11 & -0.086 & 0.1269 & 0.1644 & & -0.6 & 303 & -0.7629 & 0.220 & & -0.3 & 556 & 0.2834 & -0.3981 & 0.1296 & -0.1142 & 0.3423 & 1.2413 & -0.3 & 304 & 0.0189 & 0.3371 & 0.1871 \\
\hline 12 & -0.0519 & 0.012 & 0.1589 & & -0.5 & & -0.0382 & 0.080 & & -0 . & & 0.2649 & 0.4775 & 0.0605 & -0.0439 & 0.8894 & -0.9463 & -0.1 & 271 & 0.0172 & 0.241 & 0.1623 \\
\hline 13 & 0.036 & -0.1215 & $-0.068 ?$ & & 0.16 & & 0.9025 & -0.38 & & $0.0^{\circ}$ & & -0.0715 & 0.7535 & -0.054 & 0.0687 & 0.4082 & -2.0619 & 0.31 & 127 & -0.0127 & -0.0715 & -0.1287 \\
\hline 14 & -0.0809 & 0.1818 & 0.2677 & & -1.30 & 59 & -1.0405 & 2.261 & & -0.5 & 594 & 0.3686 & 0.938 & 0.2264 & -0.0337 & 0.1009 & 0.5755 & -1.1 & 204 & 0.0877 & -0.1637 & 0.6933 \\
\hline 15 & -0.0822 & 0.1601 & 0.1289 & & -1.0 & & -0.7022 & 1.816 & & -0.3 & 947 & 0.1917 & 0.5116 & 0.253 & -0.015 & 0.1066 & 0.1826 & -0.6 & 834 & 0.1438 & -0.1347 & 0.497 \\
\hline 16 & 0.056 & 0.043 & 0.0046 & & -0.3 & 34 & -0.1373 & 1.335 & & 0.2 & & -0.1287 & 0.4077 & 0.0678 & 0.0425 & -0.2366 & -0.1628 & -0.2 & 025 & 0.0214 & -0.9058 & 0.1143 \\
\hline & Resi & $\mathrm{e}=0.1$ & & & & & & & & & & & & & & & & & & & & \\
\hline 1 & Vine le & lgth (m) & & 5 & : & $\begin{array}{l}\text { Da } \\
\text { hal }\end{array}$ & $\begin{array}{l}\text { S to first } \\
\text { vest }\end{array}$ & & 9 & : & & lit polar ( & meter & 13 & 100 see & wt. (g) & & 17 & : & Fruit yie & l/vine (kg) & \\
\hline 2 & $\begin{array}{l}\text { Days to } \\
\text { flower }\end{array}$ & $\begin{array}{l}\text { first fem } \\
\text { ppearanc }\end{array}$ & & 6 & : & $\begin{array}{l}\text { No } \\
\text { vin }\end{array}$ & of fruit per & & 10 & : & Fle & h thickne & $\mathrm{s}(\mathrm{cm})$ & 14 & $\begin{array}{l}\text { Ascorbi } \\
\text { (mg/100 }\end{array}$ & $\begin{array}{l}\text { acid con } \\
\text { g) }\end{array}$ & & & & & & \\
\hline 3 & $\begin{array}{l}\text { Node } n \\
\text { female } \\
\text { appeara }\end{array}$ & $\begin{array}{l}\text { imber for } \\
\text { lower } \\
\text { nce }\end{array}$ & & 7 & : & Fru & $\mathrm{t}$ weight $(\mathrm{kg}$ & & 11 & : & No & of seed/ & & 15 & Crude fi & eer $(\%)$ & & & & & & \\
\hline 4 & Sex rati & & & 8 & : & $\begin{array}{l}\text { Fru } \\
(\mathrm{cm}\end{array}$ & equ. Diam & neter & 12 & : & & d wt./ fru & (g) & 16 & $\beta$ carote & e $(\mu \mathrm{g} / \mathrm{g})$ & & & & & & \\
\hline
\end{tabular}


Sex ratio, node number for first female flower appearance, days to first female flower appearance and days to first harvest registered negative and significant correlation with yield. This indicating the selection for plants with earlier node for female flower appearance and earliness would be effective in increasing the yield. These results are in conformity with the findings of Shivanand Hegde (2009), Uma Maheswari and Hari Babu (2006) in pumpkin.

Inter-correlation among the yield components need to be estimated because the importance of one component influenced the other related components. Vine length exhibited positive and significant correlation with fruit number per vine (Josephin, 2008). Days to first female flower appearance had positive and significant correlation with days to first harvest (Naik et al., 2015) in pumpkin. It was also observed that days to first female flower appearance exhibited significant negative correlation with fruit number per vine (Srinivasan, 2003). Sex ratio had positive and significant association with fruit weight, fruit equatorial diameter, seed number per fruit (Shivanand Hegde, 2009), seed weight per fruit. It was also observed that sex ratio had negative and significant association with fruit number per vine (Josephin, 2008) and carotene content. Days to first harvest exhibited significant correlation with fruit weight (Raghvendra Singh et al., 2006). Fruit number per vine had positive association with fruit weight (Murali et al., 1986 and Saikia et al., 1995), yield per vine which in accordance with the results found by the Naik et al., (2015) in pumpkin. Fruit number per vine had positive association with $\beta$ carotene content which in accordance with the results found by the Akter et al., (2013) in pumpkin. Fruit weight showed positive correlation with equatorial diameter and fruit polar diameter and flesh thickness (Srinivasan, 2003; Mukunda Lakshmi et al., 2002 and Gopalakrishnan, 1980). Fruit equatorial and polar diameter showed positive and significant association with flesh thickness and seed weight per fruit (Yadav and Ram, 2002). It also observed that carotene content (Hazara et al., 2007) was significantly and positively correlated with yield. This indicates that favorable pumpkin hybrids have industrial value as (nutraceuticals) highly possible.

\section{Path analysis}

Path analysis was carried out to find out direct and indirect effects of twelve important yield contributing characters on total yield per plant. The residual effect $(0.1273)$ indicated that most of the characters contributing towards the yield were included in the study (Table 2).

\section{Direct effects}

Number of fruit per vine exerted the highest positive direct effect (3.6399) on total yield per plant followed by sex ratio (2.2931), fruit polar diameter (1.8323), days to first harvest (1.5775), fruits equatorial diameter (0.9242), seed weight per fruit (0.8894), node number for first female flowers appearance (0.5714) and flesh thickness (0.4128). The negative direct effect on yield per plant was exerted by 100 seed weight (-2.0619), ascorbic acid content $(-1.1204)$, fruit weight $(-1.0368), \beta$ carotene (-0.9058), days to first female flower appearance (-0.3977), vine length (-0.3291), number seed per fruit $(-0.1142)$. Other characters had negligible direct positive and negative influence on total yield per plant.

\section{Indirect effects}

Vine length showed highest positive indirect effect on total yield per plant through number of fruit per vine (2.199), fruit equatorial diameter (0.3293) and 100 seed weight (0.2257). Days to first female flower appearance showed negative indirect effect 
towards total yield per plant through number of fruit per vine (1.9063), 100 seed weight ($0.6298)$ and fruit equatorial diameter (-0.3661). Number of node at first female flower appearance exerted the highest negative indirect effect on yield per plant through ascorbic acid content (-0.5249) followed by days to first harvest $(-0.4903)$ and sex ratio $(-0.4101)$. The indirect effects of number of fruit per vine were highest and positive on yield per plant through fruit polar diameter (0.4658), fruits equatorial diameter (0.34) and 100 seed weight (0.2175). The highest and positive indirect effect of flesh thickness on yield through number of fruit per vine (1.5439), fruit equatorial diameter (0.4961) and fruit equatorial diameter (0.4505) was also noticed. The highest and positive indirect effect of fruit weight on yield through number of fruit per vine (1.1963), fruit polar diameter (0.9494) and fruit equatorial diameter (0.6699) was also noticed. Seed weight per fruit showed highest positive indirect effect on total yield per plant through fruit polar diameter (04775), fruit equatorial diameter $(0.2649)$ and $\beta$ carotene (0.241). The highest and positive indirect effect of 100 seed weight through days to first harvest $(0.9025)$, fruit polar diameter $(0.7535)$ and seed weight per fruit (0.4082) on yield was also noticed. Crude fibre showed highest positive indirect effect on total yield per plant through number of fruit per vine (1.8169), fruit polar diameter (0.5116) and flesh thickness (0.253). $\beta$ carotene content exerted the highest positive indirect effect on yield per plant through number of fruit per vine (1.3354), fruit polar diameter (0.4077) and fruit weight (0.223).

Number of fruit per vine exerted the highest positive direct effect on total yield per plant (Khan et al., 2016) in snake gourd followed by sex ratio, fruit polar diameter and days to first harvest (Srikanth et al., 2015) in pumpkin, fruits equatorial diameter, seed weight per fruit, node number for first female flower appearance and flesh thickness. Akter et al., (2013) and Naik et al., (2015) in pumpkin also revealed that number of fruits per plant had the maximum direct effect on yield per plant. Vine length showed highest positive indirect effect on total yield per plant through number of fruit per vine, fruit equatorial diameter and 100 seed weight. The similar results were also reported by Khan et al., (2016) in snake gourd. Days to first female flower appearance showed negative indirect effect towards total yield per plant through number of fruit per vine (Srikanth et $a l ., 2015), 100$ seed weight and fruit equatorial diameter. The indirect effects of number of fruit per vine were highest and positive on yield per plant through fruit polar diameter, fruits equatorial diameter and 100 seed weight. Highest positive indirect effect of fruit weight on yield through number of fruit per vine, fruit polar diameter and fruit equatorial diameter was also noticed. The similar trends of results were reported by Srikanth et al., (2015) in pumpkin.

From the foregoing findings, it may be concluded that an intensive selection of fruit number per vine, fruit weight, fruit equatorial diameter and quality trait i.e., crude fibre and ascorbic acid content were found to be important traits in improving the yield per vine as adjudged by their positive and significant association.

\section{References}

Akter, S., M.G. Rasul, A.K.M. Aminul Islam and M.M. Hossain. 2013. Genetic variability, correlation and path coefficient analysis of yield and quality traits in pumpkin (Cucurbita moschata Duch ex Poir.). Bangladesh J. Pl. Breed. Genet., 26(1): 25-33.

Bose T K, Som M G. Vegetable crops in India. Naya Prakash, Calcutta, India.1998, pp 92-95.

Gomez, K. A. and A. A. Gomez. 1984. Statistical Procedures for Agricultural Research, $2^{\text {nd }}$ Edition. John Wiley and Sons, New York.

Gopalakshishnan, T.R., P.K. GopalaKrishnan and K.V. Peter. 1980. Variability, Heritability and correlation among some polygeneic characters in pumpkin (Cucurbita moschata Poir.). Indian J. Agric. Sci., 50(12): 925-930. 
Graffius. 1964. Components of grain yield in oats. A geometrical interpretation. Agron. J., 48: 419-423.

Hazara, P., A.K. Mandal, A.K. Dutta, D. Sikadar and M.K. Pandit.2007. Breeding Pumpkin (Cucurbita moschata Duch. ex Poir.) for High Yield and Carotene Content. Acta Hort., 752: 432-434.

Josephin, P. 2008. Studies on development of $F_{1}$ hybrids in ash gourd [Benincasa hispida (Thunb.) Cogn.] for yield and quality. M.Sc. Thesis, Tamil Nadu Agric. Univ., Coimbatore.

Kalloo, G. 1998. Vegetable Breeding, Vol. I, CRC press Inc. Boca Raton, Florida.

Khan, A.S., R. Eyasmin, M. Rashid, S. Ishtiaque, and A.K. Chaki. 2016. Variability, heritability, character association, path analysis and morphological diversity in snake gourd. Agriculture and Natural Resources. 50(3): 483-489

Mukunda Lakshmi, L., K. Haribabu and G.L.K. Reddy. 2002. Character association and path coefficient studies in pumpkin (Cucurbita moschata Duch. ex Poir). The Andhra Agric. J., 49(1-2): 80-85.

Murali, B., K. Hari Babu and V. Parthasarathy Reddy. 1986. Correlation studies in bottle gourd (Lagenaria siceraria (Monia) Slandl). South Indian Hort., 34(5): 338340.

Naik, L.M., V.M. Prasad and P. RajyaLaxmi. 2015. A study on character association and path analysis in Pumpkin (Cucurbita moschata Duch. ex Poir.) Inter. J. Advanced Res., 3(1): 1030-1034.

Pandey, S., J. Singh, A.K. Upadhyay and D. Ram. 2002. Genetic variability for antioxidants and yield components in pumpkin (Cucurbita moschata Duch. ex Poir). Veg. Sci., 29:123-126.

Raghavendra Singh, S. Kumar and S.K. Dixit. 2006. Correlation coefficient and path analysis in bottle gourd (Lagenaria siceraria (Molina) Standl.). Prog. Hort., 38(2): 256-261.

Saikia, J., A. Shadeque and G.C. Bora. 1995. Genetic studies in cucumber-correlation and path coefficient analysis. Haryana J. Hort. Sci., 24(2): 126-130.

Shivanand Hegde. 2009. Studies on heterosis in ridge gourd. M.Sc. Thesis, Tamil Nadu Agric. Univ., Coimbatore.

Srikanth, M., S.G. Bharad, N.R. Potdukhe and B. Ravinayak. 2015. Character association and path analysis in pumpkin (Cucurbita moschata Duch ex. Poir). Res. J. Agric. Sci., 6(3): 495-498.

Srinivasan, M. 2003. Studies on genetic parameters and characterization in pumpkin (Cucurbita moschata Duch ex. Poir). M.Sc. Thesis, Tamil Nadu Agric.Univ., Coimbatore.

Thamburaj S, Singh N (Eds.) Vegetables, Tuber Crops and Spices. 2004, ICAR, New Delhi.

Tindall H D. Vegetables in the Tropics. Macmillan Education, London. 1987, pp 166.

Uma Maheswari., K. Hari Babu. 2006. Correlation and Path coefficient analysis in Pumpkin (Cucurbita moschata Duch. ex Poir). The Orissa J. Horti., 34(2): 6-12.

Yadav R.K. and H.H. Ram. 2002. Correlation and path coefficient analysis in muskmelon. Haryana J. Hort. Sci., 31(1\&2): 74-76.

\section{How to cite this article:}

Kumar, R., V. Rajasree, S. Praneetha, S. Rajeswari and Tripura, U. 2018. Correlation and Path Coefficient Analysis Studies in Pumpkin (Cucurbita moschata Duch. Ex poir) for Yield and Quality Traits. Int.J.Curr.Microbiol.App.Sci. 7(05): 3067-3075. doi: https://doi.org/10.20546/ijcmas.2018.705.358 